\title{
An Analytical Study of Profitability and Liquidity Postions of Selected Life Insurance Companies in India
}

\author{
Ahmed Mahdi Abdulkareem, Bhavika Rameshbhai Nagvadiya \\ Department of Commerce, Saurashtra University, Gugarat, India \\ Email address: \\ Ahmed1997alabadi@gmail.com (A. M. Abdulkareem), bhavika.nagvadiya155@gmail.com (B. R. Nagvadiya)
}

\section{To cite this article:}

Ahmed Mahdi Abdulkareem, Bhavika Rameshbhai Nagvadiya. An Analytical Study of Profitability and Liquidity Postions of Selected Life Insurance Companies in India. International Journal of Finance and Banking Research. Vol. 7, No. 2, 2021, pp. 58-66.

doi: $10.11648 /$ j.jifbr.20210702.14

Received: January 5, 2021; Accepted: March 17, 2021; Published: March 26, 2021

\begin{abstract}
The main objective of this study is to find out the truth which is hidden and which has not been discovered as yet. And this study used to evaluate the liquidity and profitability position of selected HDFC Standard Life insurance Co. Ltd. and SBI Life Co. Ltd. In addition to evaluate which company is performing best among the selected companies and make suggestions for improvement in financial or liquidity position of the selected companies. This study focused on knowing insurance sectors and it is performance in India through study conceptual framework of profitability and liquidity. This study deals with data analysis and interpretation of the different ratios which are useful for current assets, current liabilities, net profit, gross profit, all are use. It includes hypothesis testing by using t-test of HDFC and SBI companies. Simple random sampling was used to select the sample from top banks in India. The study relies largely on secondary data that was obtained from the annual reports and financial statements of the selected HDFC and SBI standard life insurance companies. In addition to the annual reports, different publications have also been used in this study. The study is made for a period of five years from 201415 to $2018-19$.
\end{abstract}

Keywords: Profitability, Liquidity, Insurance, Performance, Financial

\section{Introduction}

Wherever there is uncertainty there is risk. The risk can't be averted. It involves multiple losses. And so, the risk is uncertainty of financial losses. We do not have any command on uncertainties. The insurance is a co- operative device to spread the loss. Further, it is also a social device to accumulate funds to meet uncertain losses. The main function of insurance is to provide protection against the possible chances of generating losses. It eliminates worries and miseries of losses at destruction of property and death. It also provides capital to the society as the accumulated funds are invested in the productive heads. The product of insurance benefits the industry, the business, an individual and a group of persons. Hence, the insurance is the outcome of man's constant search for security and finding out ways and means of ameliorating the hardships arising out of calamities. Here, the persons exposed to similar risk contribute some amount periodically and those who actually face the loss are indemnified out of these funds. Life Insurance is a contract for payment of a sum of money to the person assured (or failing him/her, to the person entitled to receive the same) on the happening of the event insured against. Usually the insurance contract provides for the payment of an amount on the date of maturity or at specified dates at periodic intervals or at the unfortunate death if it occurs earlier. So, there is a price to be paid for this benefit. Among other things, the contract also provides for the payment of premiums by the assured. Life Insurance is universally acknowledged as a tool to eliminate risk, substitute 3 certainties for uncertainty and ensure timely aid of the family in the unfortunate event of the death of the breadwinner. In other words, it is the civilized world's partial solution to the problems caused by death In a nutshell, life insurance helps in two ways: premature death, which leaves dependent families to fend for itself and old age without visible means of support [11]. In the era of uncertainty where people want to insure their life and family's future in any unforeseen event, life insurance sector offers its services to deal with such situation. Life insurance is a contract between two parties.[13] Life insurance is a professional service which is characterized by high 
involvement of the consumers, due to the importance of tailoring specific need, the variability of the products available, the complexity involved in the policies and processes and ultimately the need to involve the consumer in every aspect of the transaction. Life insurance more fondly known as Life Assurance has, in recent times ceased to be only a 'Protection' or 'Legacy' for the family and has turned into an important investment outlet [15].

\section{Review of Literature}

"Kishore. R. B. "A Holistic View of Insurance Reforms and a Blue Print for Strengthening LIC" In his article "A Holistic View of Insurance Reforms and a Blue Print for Strengthening Life Insurance Company" stated that there is an Enormous scope for a big breakthrough and an accelerated growth with keen healthy Competition. He forecast that the Industry would generate 8 to 10 lakhs jobs in the Next 5 to 7 years [1]". "Kapse S. and Kodwanid G. "Insurance as an Investment Option" they argued that in the changing scenario for the insurance sector after liberalization of Indian insurance sector, it's a good opportunities for insurance sector to expand its market base. Finally, their study has suggested for improving and modifying the features the products to make them more liquid or short term schemes [2]". While "Krishnamurthy S, Mony S. V., Jhaveri N., Bakhshi S, Bhat S and Dixit M. R."Insurance Industry in India: Structure, Performance and Future Challenges" Their study has clearly discussed the status and growth of Indian insurance industry after liberalization and future challenges and opportunities with regard to insurance. The future growth of this sector will depend on how effectively the insurers are meeting the expectations of their customers and able to change the perceptions of the Indian consumers and make them aware of the insurable risks. The process of reforms has enhanced competition, provided number of alternatives to the customers and improved the efficiency level of the industry. The insurers have responsibilities not only to social sector but also to rural sectors [3]". "Rastogi S., and Sarkar R.,"Competitiveness among the Indian life insurers" Their study has dealt with enhancing competitiveness among the Indian life insurers. The Govt of India has identified the root of causes. Finally, Govt of India has adopted and completed the liberalization process in 2000 with the sole motive is to par with international insurance standard. Despite of huge population and abundance growth opportunity, India is one of the least insured countries compared to the other developed nations in the world. Opening of this sector for private players, it was aimed at fostering competition and innovation through launching the variety of products. Finally, their study has suggested for formulating the alternative strategies that can facilitate the development of sound policies and practices leading to a globally competitive insurance industry [4]". "Raman. N. and Gayathri. C. "A study Customers Awareness towards New Insurance Companies" In their article "A Study On Customer's Awareness towards New Insurance Companies", Indian journal of Marketing revealed that customers are now looking at insurance as complete financial Solutions offering stable returns coupled with total protection. Companies will need to constantly innovate in terms of product development to meet over changing consumer Needs. Understanding the customer better will enable insurance companies to design appropriate products, determine price correctly and increase profitability. In the Present scenario a key differentiated would be professional customer service in terms of quality of advice on enhancing the customer convenience [5]". "Murthy R. Babu and Ansari D., "The Performance of Life Insurance Corporation of India" The objectives of this study are to analyze the growth and development of LIC business before and after liberalization. There is no doubt that Indian life insurance industry has grown significantly after the entry of private players in the mean time the market share of LIC has declined gradually over a period of years. The study has suggested that LIC should adopt: an effective marketing strategy with innovative products, the better customer services to satisfy existing policyholders, should attract new customers to increase insurance-density and penetration levels in order to fulfill customer needs, and should be reachable their expectations of the Indian insurance market [6]". "Bodla, B. S. and Sushma Rani Verma. "Life Insurance Policies in Rural Area Understanding Buyer Behavior" revealed that insurance sector plays a very important role in the Development of any economy and it provides long-term funds for infrastructure Development and at the same time strengthens the risk taking ability [7]". "C. Barathi, Balaji C. D. and Meithei Ch. Ibohal "- "Innovative Strategies to Catalyse Growth of Indian Life Insurance Sector-An Analytical Review" Their study has clearly examined about the impact of global recession on the fastest growing Indian insurance market. This study also discusses the strategic options that can be effectively implemented by the insurers to improve the coverage and penetration of life insurance into untapped areas. The suggestions of the study are to focus and launch new and innovative products to target new segments and to implement innovative strategies to achieve sustainable growth and development and ensuring profitability of business [8]". "Sonal Nena. "Performance Evaluation of Life Insurance Corporation (LIC) of India" He found that the insurance industries in India now a day have taken a giant shape especially after privatization and introduction of Insurance Regulatory \& Development Authority (IRDA). Life Insurance Corporation of India is one of the most significant public sector which plays excellent job in selling its products. But since last few years it is facing tremendous competition as many private players have emerged. The idea behind this study therefore to know the growth and performance of LIC. The researcher is going to analyze the major source of income (Premium Earned) of the sampled unit, as well as the significant heads of expenses of LIC to measure the performance during the period of the study [9]". as well as the "Keerthi, P. and Vijayalakshmi. R. "A Study on the Expectations and Perceptions of the Services in Private Life Insurance Companies" they revealed that the policyholders' 
expectations are well met in the case of certain factors reacting to service quality. But in the case of other variables, there exists a significant gap which means that policyholders have experienced low levels of service as against their expectations. If all the players in the Life insurance industry focus on the effective delivery of services, they can win the hearts of customers and anticipate their increased market share [10]". "Irem Hussanie and Bashir Ahmad Joo"), "Determinants of Profitability of Life Insurers in India- Panel Evidence" they found that liquidity, loss ratio, investment performance, operating margin, premium growth and tangibility were significant in determining the profitability, as measured by ROA, of Indian life insurers. Also, they noted that leverage, commission ratio and size are insignificant in explaining the profitability as measured by ROA. Charumathi (2012) revealed that profitability of life insurers was positively and significantly influenced by the size and liquidity. Moreover, the study depicts that the leverage, premium growth and logarithm of equity capital had negatively and significantly influenced the profitability of Indian life insurers [12]"."Deyganto and Alemu)" Factors affecting financial performance of insurance companies operating in Hawassa city administration" found that the underwriting, premium growth, solvency ratio, growth rate of GDP, and the rate of inflation had effect on financial performance of the insurance companies operating in
Hawassa city [14]".

\section{Methodology}

The sample of the study includes only two banks SBI and HDFC. Simple random sampling was used to select the sample from top banks in India. The study relies largely on secondary data that was obtained from the annual reports and financial statements of the selected banks. In addition to the annual reports, different publications have also been used in this study. The study is made for a period of five years from 2014-15 to 2018-19. The most appropriate parametric and non- parametric tests are used in data analysis. The data obtained is presented through different graphs and tables. Data has been converted in to relative measure such as ratios, percentages, indices rather than the absolute data. The data has been analyzed and hypotheses have been tested at 5\% level of significance, by employing $t$-test, ANOVA technique. In this study, the used tools for data analysis are gross profit ratio, net profit ratio, return on assets, current ratio and quick ratio.

Data analysis:

GROSS PROFIT MARGIN RATIO

Gross profit margin is calculated as follows:

Gross Profit Ratio $=\frac{\text { Sales }- \text { cost of goods sold }}{\text { Sales }} \times 100$

Table 1. Gross Profit Ratios During 2014-2015 to 2018-19.

\begin{tabular}{llllll}
\hline \multirow{2}{*}{ Year } & \multicolumn{2}{l}{ SBI Life Insurance } & & \multicolumn{2}{c}{ HDFC Standard Life Insurance } \\
\cline { 2 - 5 } & GP & Income & Ratio (\%) & GP & Income \\
\hline $2014-15$ & 829.33 & 983.38 & 84.33 & 804.58 & 871.78 \\
$2015-16$ & 855.11 & 969.51 & 88.20 & 834.99 & 887.08 \\
$2016-17$ & 974.57 & 1056.15 & 92.28 & 914.14 & 1013.2 \\
$2017-18$ & 1184.45 & 1281.46 & 92.43 & 1126.74 & 1282.46 \\
$2018-19$ & 1372.86 & 1504.16 & 91.27 & 1289.88 & 1615.3 \\
Maximum & 1372.86 & 1504.16 & 92.43 & 1289.88 & 1615.3 \\
Minimum & 829.33 & 969.51 & 84.33 & 804.58 & 87.13 \\
Mean & 1043.26 & 1158.93 & 89.70 & 994.06 & 87.78 \\
\hline
\end{tabular}

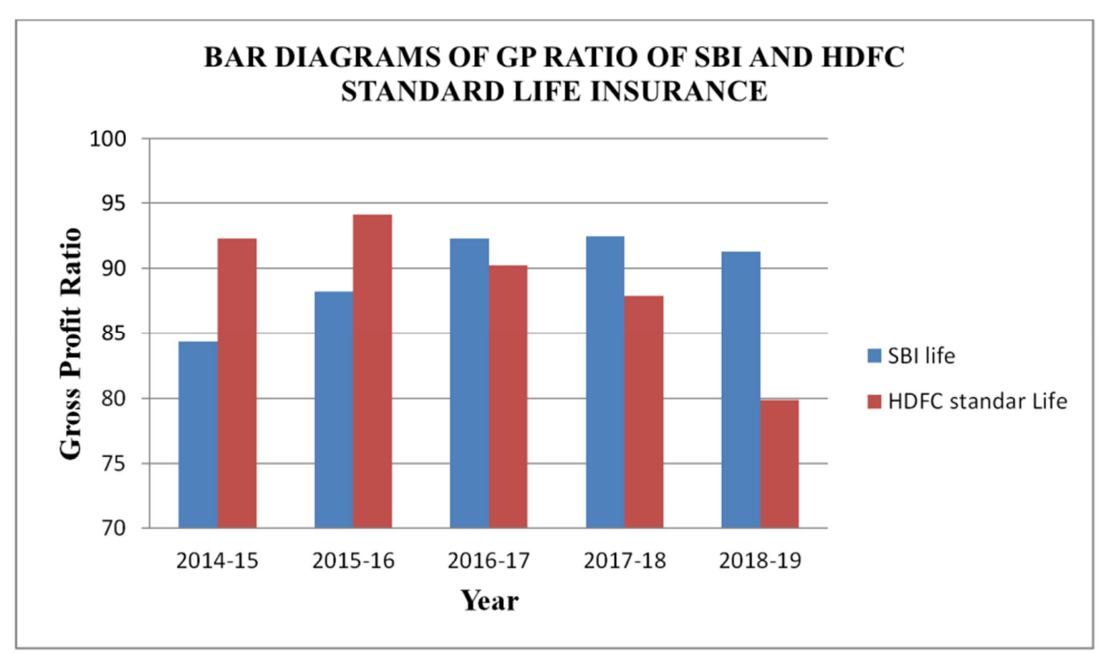

Figure 1. Gross Profit Ratio During 2014-15 to 2018-19.

The above table 1. Indicates the Gross Profit Ratio of the SBI Life Insurance and HDFC Standard Life Insurance during the period of the study from 2014-15 to 2018-19. In SBI Life Insurance Shows Mix Trend With an average 89.70 
which is highest in the selected sample the ratio moved between 92.28 in $2016-17$ to 91.27 in 2018-19 during the period of stud. The Gross Profit ratio of HDFC standard life insurance shows Mix trend with an average 88.87 which is second in the selected selected sample the ratio moved between 90.22 in 2016-17 to 79.89 in 2018-19 during the period of the study.

HYPOTHESIS: $\mathrm{H}_{0}=$ There is no significance difference of gross profit in selected SBI life insurance Co. and HDFC Standard life insurance Co. $\mathrm{H}_{1}=$ There is a significance difference of gross profit in selected SBI life insurance Co. and HDFC Standard life insurance Co.

Table 2. Gross Profit Two-Sample Assuming Equal Variances.

\begin{tabular}{lll}
\hline t-Test: Two-Sample Assuming Equal Variances & & \\
\hline Particulars & SBI Life Insurance GP Ratio (\%) & HDFC Life Insurance GP Ratio (\%) \\
\hline Mean & 89.70224 & 88.87084 \\
Variance & 11.89744 & 30.87474 \\
Observations & 5 & 5 \\
Df & 8 & \\
t Stat & 0.284257 & \\
P $(T<=t)$ one-tail & 0.391716 & \\
t Critical one-tail & 1.859548 & \\
P $(\mathrm{T}<=t)$ two-tail & 0.783432 & \\
t Critical two-tail & 2.306004 & \\
\hline
\end{tabular}

(At $0.05 \%$ level of Significance)

$5 \%$ level of significance and at 8 degree of freedom the table value of " $t$ " is 2.306

The above table 2. Shows that the result of $t$ test. From the above table, the researcher can be analyzed that the calculated value is 0.28 and table value is 2.306 . It is indicate that the calculation value is less than the table value. So null hypothesis is accepted and at the same time alternative hypothesis is rejected therefore, there is no significant difference in Gross Profit Ratio of SBI life insurance and
HDFC standard life insurance during study period.

$$
\text { Net Profit Margin Ratio }=\frac{\text { Net Profit }}{\text { Income }} \times 100
$$

Where, Net Profit=Net Operating Profit + Non-Operating Income - Non Operating Expenses

Table 3. Net Profit Ratios During 2014-15 to 2018-19.

\begin{tabular}{llllll}
\hline \multirow{2}{*}{ Year } & SBI Life Insurance & & & \multicolumn{3}{l}{ HDFC Standard Life Insurance } \\
\cline { 2 - 6 } & NP & Income & Ratio (\%) & NP & Income \\
\hline $2014-15$ & 814.87 & 983.38 & 82.86 & 785.51 & 871.78 \\
$2015-16$ & 844.1 & 969.51 & 87.06 & 818.4 & 887.08 \\
$2016-17$ & 954.65 & 1056.15 & 90.39 & 892.13 & 1013.2 \\
$2017-18$ & 1150.38 & 1281.46 & 89.77 & 1109 & 1282.46 \\
$2018-19$ & 1326.8 & 1504.16 & 88.21 & 1276.79 & 1615.3 \\
Maximum & 1326.80 & 1504.16 & 90.39 & 1276.79 & 82.25 \\
Minimum & 814.87 & 969.51 & 82.86 & 785.51 & 86.05 \\
Mean & 1018.16 & 1158.93 & 87.66 & 976.37 & 871.78 \\
\hline
\end{tabular}

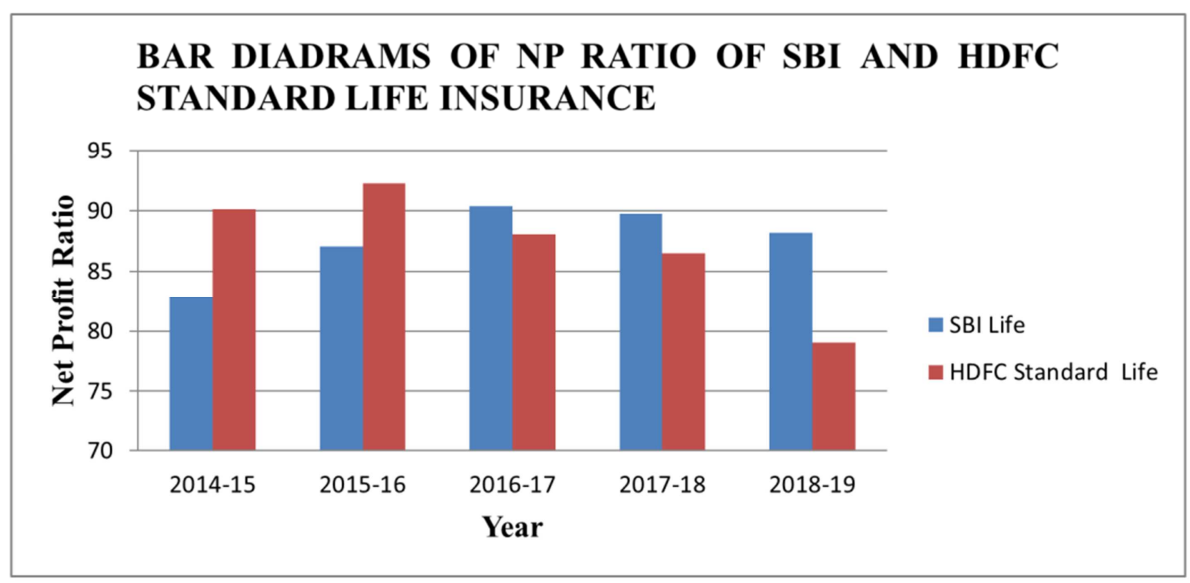

Figure 2. Net Profit Ratios During 2014-15 to 2018-19.

DATA ANALYSIS: The above table 3. Indicates the Net Profit Ratio of the SBI Life Insurance and HDFC Standard Life Insurance during the period of the study from 2014-15 to
2018-19. In SBI Life Insurance Shows Mix Trend With an average 87.66 which is highest in the selected sample the ratio moved between 90.39 in $2016-17$ to 88.21 in $2018-19$ 
during the period of study. The Net Profit ratio of HDFC standard life insurance shows Mix trend with an average 87.18 which is second in the selected sample the ratio moved between 88.05 in 2016-17 to 79.04 in 2018-19 during the period of the study.
HYPOTHESIS: $\mathrm{H}_{0}=$ There is no significance difference of Net Profit ratio in selected SBI life insurance Co. and HDFC Standard life insurance Co. $\mathrm{H}_{1}=$ There is a significance difference of Net Profit ratio in selected SBI life insurance Co. and HDFC Standard life insurance Co.

Table 4. Net Profit Ratio Two-Sample Assuming Equal Variance.

\begin{tabular}{lll}
\hline t-Test: Two-Sample Assuming Equal Variances & & \\
\hline Particulars & SBI Life Insurance NP Ratio (\%) & HDFC Standard Life Insurance NP Ratio (\%) \\
\hline Mean & 87.658 & 87.182 \\
Variance & 8.90187 & 25.43797 \\
Observations & 5 & 5 \\
Df & 8 & \\
$\mathrm{t}$ Stat & 0.181632191 & \\
$\mathrm{P}(\mathrm{T}<=\mathrm{t})$ one-tail & 0.430194535 & \\
$\mathrm{t}$ Critical one-tail & 1.859548033 & \\
$\mathrm{P}(\mathrm{T}<=\mathrm{t})$ two-tail & 0.86038907 & \\
$\mathrm{t}$ Critical two-tail & 2.306004133 & \\
\hline
\end{tabular}

(At $0.05 \%$ level of significance)

$5 \%$ level of significance and at 8 degree of freedom the table value of "t" is 2.306

The above table 4. Shows that the result of $t$ test. From the above table, the researcher can be analyzed that the calculated value is 0.181 and table value is 2.306 . It is indicate that the calculation value is less than the table value. So null hypothesis is accepted and at the same time alternative hypothesis is rejected therefore, there is no significant difference in Net profit ratio of SBI life insurance and HDFC standard life insurance during study period.

$$
\text { Return on Assets Ratio }=\frac{\text { Net Income }}{\text { Total Assets }} \times 100
$$

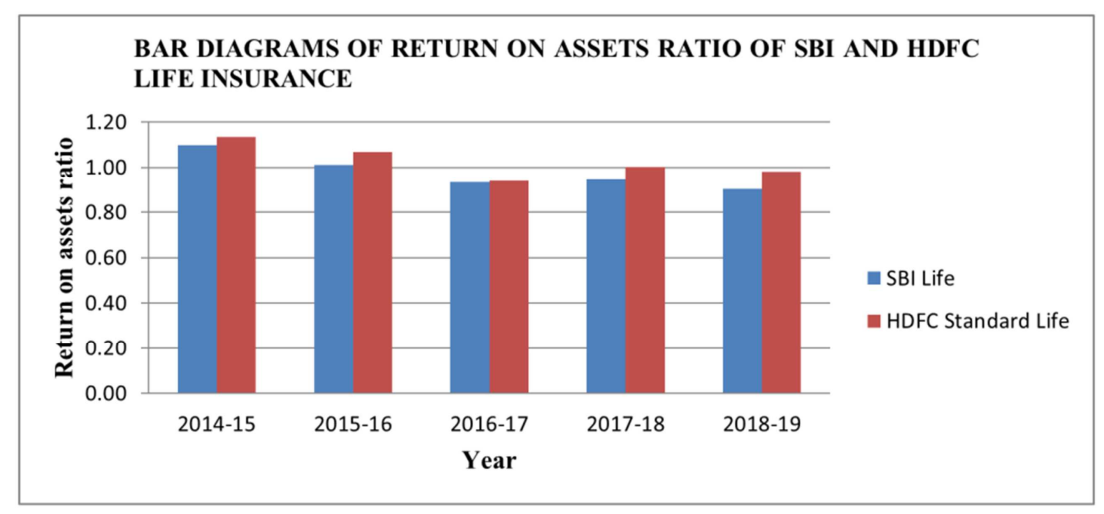

Figure 3. Return On Assets Ration During 2014-15 to 2018-19.

Table 5. Return On Total Assets Ratios During 2014-15 to 2018-19.

\begin{tabular}{|c|c|c|c|c|c|c|}
\hline \multirow{2}{*}{ Year } & \multicolumn{3}{|c|}{ SBI Life Insurance } & \multicolumn{3}{|c|}{ HDFC Standard Life Insurance } \\
\hline & Net Income & Total Assets & Ratio (\%) & Net Income & Total Assets & Ratio (\%) \\
\hline $2014-15$ & 814.87 & 74120.53 & 1.10 & 785.51 & 69308.55 & 1.13 \\
\hline $2015-16$ & 844.1 & 83429.07 & 1.01 & 818.4 & 76548.69 & 1.07 \\
\hline 2016-17 & 954.65 & 102239.56 & 0.93 & 892.13 & 95106.15 & 0.94 \\
\hline 2017-18 & 1150.38 & 121720.44 & 0.95 & 1109 & 110481.5 & 1.00 \\
\hline 2018-19 & 1326.8 & 146733.85 & 0.90 & 1276.79 & 130000.8 & 0.98 \\
\hline Maximum & 1326.8 & 146733.85 & 1.10 & 1276.79 & 130000.8 & 1.13 \\
\hline Mean & 1018.16 & 105648.69 & 0.98 & 976.36 & 96289.13 & 1.03 \\
\hline
\end{tabular}

The above table 5. indicates the Return on Total Assets of the SBI Life Insurance and HDFC Standard Life Insurance during the period of the study from 2014-15 to 2018-19. In SBI Life Insurance Shows Mix Trend With an average 0.98 which is lowest in the selected sample the ratio moved between 0.93 in 2016-17 to 0.90 in 2018-19 during the period of study. The Return on Total Assets of HDFC standard life insurance shows Mix trend with an average 1.03 which is second in the selected sample the ratio moved between 0.94 in 2016-17 to 0.98 in 2018-19 during the period of the study. HYPOTHESIS: $\mathrm{H}_{0}=$ There is no significance difference of Return on assets ratio in selected SBI Life insurance Co. and HDFC Standard Life insurance Co. $\mathrm{H}_{1}=$ There is a significance difference of Return on assets ratio in selected 
SBI Life insurance Co. and HDFC Standard Life insurance Co.

Table 6. Return On Assets Ratios Two-Sample Assuming Equal Variances.

\begin{tabular}{lll}
\hline t-Test: Two-Sample Assuming Equal Variances & & \\
\hline Particulars & SBI Life Insurance ROA Ratio (\%) & HDFC Standard Life Insurance ROA Ratio (\%) \\
\hline Mean & 0.978840661 & 1.025288041 \\
Variance & 0.006088758 & 0.005884075 \\
Observations & 5 & 5 \\
Df & 8 & \\
t Stat & -0.949178228 & \\
P $(\mathrm{T}<=t)$ one-tail & 0.185159096 & \\
t Critical one-tail & 1.859548033 & \\
P $(\mathrm{T}<=t)$ two-tail & 0.370318192 & \\
$\mathrm{t}$ Critical two-tail & 2.306004133 & \\
\hline
\end{tabular}

(At $0.05 \%$ level of significance)

$5 \%$ level of significance and at 8 degree of freedom the table value of " $t$ " is 2.306

The above table 6 . Shows that the result of $t$ test. From the above table, the researcher can be analyzed that the calculated value is -0.949 and table value is 2.306 . It is indicate that the calculation value is less than the table value. So null hypothesis is accepted and at the same time alternative hypothesis is rejected therefore, there is no significant difference in Return on Total Asset of SBI life insurance and HDFC standard life insurance during study period.

\section{CURRENT RATIO:}

$$
\text { Current Ratio }=\frac{\text { Current Assets }}{\text { Current Liabilities }}
$$

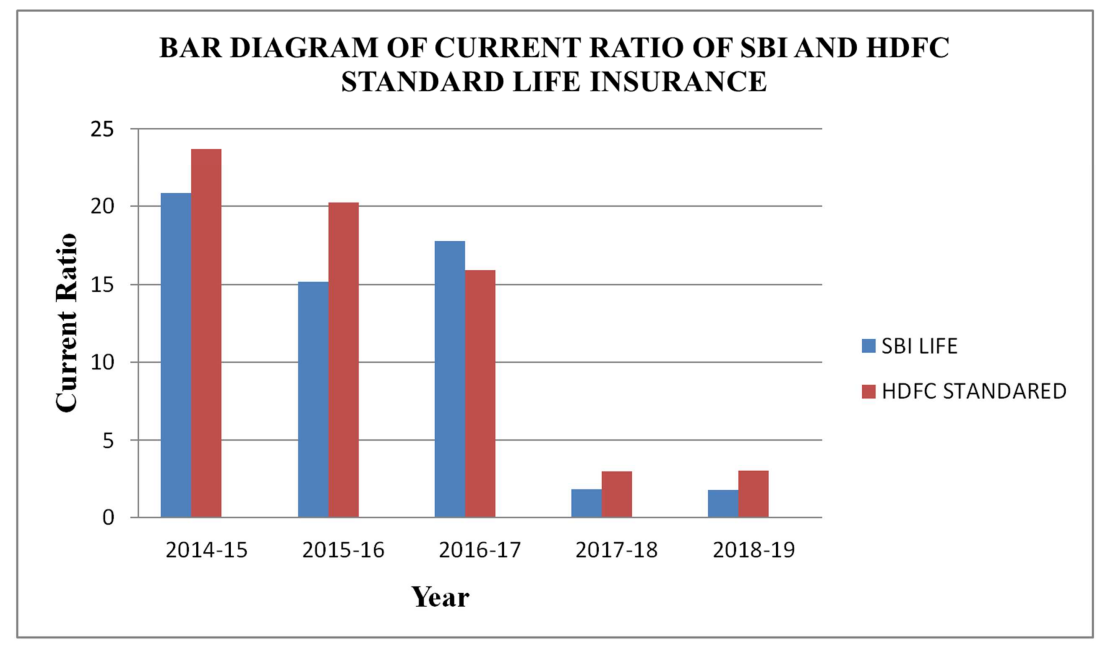

Figure 4. Current Ratio During 2014-15 to 2018-19.

Table 7. Current Ratio During 2014-15 to 2018-19.

\begin{tabular}{|c|c|c|c|c|c|c|}
\hline \multirow{2}{*}{ Year } & \multicolumn{3}{|c|}{ SBI Life Insurance } & \multicolumn{3}{|c|}{ HDFC Standard Life Insurance } \\
\hline & Current Assets & Current Liabilities & Ratio (\%) & Current Assets & Current Liabilities & Ratio (\%) \\
\hline $2014-15$ & 39245.62 & 1883.92 & 20.83 & 48403.6 & 2041.75 & 23.71 \\
\hline $2015-16$ & 41037.46 & 2704.51 & 15.17 & 51650.66 & 2553.34 & 20.23 \\
\hline 2016-17 & 53521.11 & 3014.32 & 17.76 & 60851.05 & 3820.12 & 15.93 \\
\hline $2017-18$ & 6532.37 & 3564.67 & 1.83 & 13930.45 & 4646.39 & 3.00 \\
\hline 2018-19 & 6641.41 & 3736.01 & 1.78 & 15803.03 & 5117.89 & 3.09 \\
\hline Maximum & 53521.11 & 3736.01 & 20.83 & 60851.05 & 5117.89 & 23.71 \\
\hline Mean & 29395.59 & 2980.69 & 11.47 & 38127.76 & 3635.90 & 13.19 \\
\hline
\end{tabular}

The above table 7. Indicates the Current Ratio of the SBI Life Insurance and HDFC Standard Life Insurance during the period of the study from 2014-15 to 2018-19. In SBI Life Insurance Shows Mix Trend With an average 11.47 which is lowest in the selected sample the ratio moved between 17.76 in 2016-17 to 1.78 in 2018-19 during the period of study. The Current Ratio of HDFC standard life insurance shows continuously decreasing trend with an average 13.19 which is second in the selected sample the ratio moved between 15.93 in 2016-17 to 3.09 in 2018-19 during the period of the study. HYPOTHESIS: $\mathrm{H}_{0}=$ There is no significance difference of Current ratio in selected SBI Life insurance Co. and HDFC Standard Life insurance Co. $\mathrm{H}_{1}=$ There is no significance difference of Current ratio in selected SBI Life insurance Co. 
and HDFC Standard Life insurance Co.

Table 8. Current Ratio Two-Sample Assuming Equal Variance.

\begin{tabular}{lll}
\hline t-Test: Two-Sample Assuming Equal Variances & & \\
\hline Particular & SBI Life Insurance Ratio (\%) & HDFC Standard Life insurance Ratio (\%) \\
\hline Mean & 11.474 & 413.746 \\
Variance & 81.92233 & 809358.7 \\
Observations & 5 & 5 \\
Df & 8 & \\
t Stat & -0.999798117 & \\
P $(\mathrm{T}<=t)$ one-tail & 0.173342708 & \\
t Critical one-tail & 1.859548033 & \\
P $(\mathrm{T}<=t)$ two-tail & 0.346685416 & \\
$\mathrm{t}$ Critical two-tail & 2.306004133 & \\
\hline
\end{tabular}

(At $0.05 \%$ level of significance)

$5 \%$ level of significance and at 8 degree of freedom the table value of " $t$ " is 2.306

The above table 8 . Shows that the result of $t$ test. From the above table, the researcher can be analyzed that the calculated value is -0.999 and table value is 2.306 . It is indicate that the calculation value is less than the table value. So null hypothesis is accepted and at the same time alternative hypothesis is rejected therefore, there is no significant difference in Current Ratio of SBI life insurance and HDFC standard life insurance during study period.

QUICK RATIO:

Quick Ratio $=\frac{\text { Current assets- Inventories }}{\text { Current Liabilities- Bank Overdraft }}$

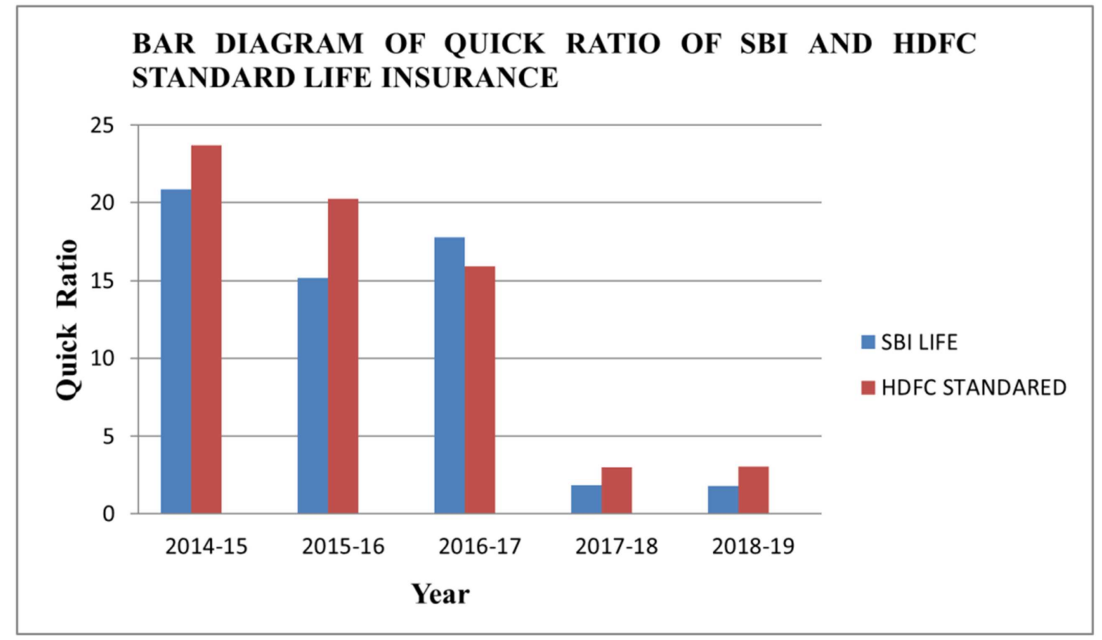

Figure 5. Quick Ratio During 2014-15 to 2018-19.

Table 9. Quick Ratio During 2014-15 to 2018-19.

\begin{tabular}{|c|c|c|c|c|c|c|}
\hline \multirow{2}{*}{ Year } & \multicolumn{3}{|c|}{ SBI Life Insurance } & \multicolumn{3}{|c|}{ HDFC Standard Life Insurance } \\
\hline & Current Assets & Current Liabilities & Ratio (\%) & Current Assets & Current Liabilities & Ratio (\%) \\
\hline 2014-15 & 39245.62 & 1883.92 & 20.83 & 48403.6 & 2041.75 & 23.71 \\
\hline $2015-16$ & 41037.46 & 2704.51 & 15.17 & 51650.66 & 2553.34 & 20.23 \\
\hline 2016-17 & 53521.11 & 3014.32 & 17.76 & 60851.05 & 3820.12 & 15.93 \\
\hline 2017-18 & 6532.37 & 3564.67 & 1.83 & 13930.45 & 4646.39 & 3.00 \\
\hline 2018-19 & 6641.41 & 3736.01 & 1.78 & 15803.03 & 5117.89 & 3.09 \\
\hline Maximum & 53521.11 & 3736.01 & 20.83 & 60851.05 & 5117.89 & 23.71 \\
\hline Mean & 29395.59 & 2980.69 & 11.47 & 38127.76 & 3635.90 & 13.19 \\
\hline
\end{tabular}

The above table 9. Indicates the Quick Ratio of the SBI Life Insurance and HDFC Standard Life Insurance during the period of the study from 2014-15 to 2018-19. In SBI Life Insurance Shows Mix Trend With an average 11.47 which is lowest in the selected sample the ratio moved between 17.76 in 2016-17 to 1.78 in 2018-19 during the period of study. The Quick Ratio of HDFC standard life insurance shows continuously decreasing trend with an average 13.19 which is second in the selected sample the ratio moved between 15.93 in 2016-17 to 3.09 in 2018-19 during the period of the study. HYPOTHESIS: $\mathrm{H}_{0}=$ There is no significance difference of Quick ratio in selected SBI Life insurance Co. and HDFC Standard Life insurance Co. $\mathrm{H}_{1}=$ There is no significance difference of Quick ratio in selected SBI Life insurance Co. 
and HDFC Standard Life insurance Co.

Table 10. Quick Ratio Two-Sample Assuming Equal Variance.

\begin{tabular}{lll}
\hline t-Test: Two-Sample Assuming Equal Variances & & \\
\hline Particular & SBI Life Insurance Ratio (\%) & HDFC Standard Life insurance Ratio (\%) \\
\hline Mean & 11.474 & 413.746 \\
Variance & 81.92233 & 809358.7 \\
Observations & 5 & 5 \\
Df & 8 & \\
t Stat & -0.999798117 & \\
P $(\mathrm{T}<=t)$ one-tail & 0.173342708 & \\
t Critical one-tail & 1.859548033 & \\
P $(\mathrm{T}<=t)$ two-tail & 0.346685416 & \\
$\mathrm{t}$ Critical two-tail & 2.306004133 & \\
\hline
\end{tabular}

(At $0.05 \%$ level of significance)

$5 \%$ level of significance and at 8 degree of freedom the table value of " $\mathrm{t}$ " is 2.306

The above table 10. Shows that the result of $t$ test. From the above table, the researcher can be analyzed that the calculated value is -0.999 and table value is 2.306 . It is indicate that the calculation value is less than the table value. So null hypothesis is accepted and at the same time alternative hypothesis is rejected therefore, there is no significant difference in Quick Ratio of SBI life insurance and HDFC standard life insurance during study period.

\section{Findings}

\subsection{Based on Gross Profit Ratio}

The gross profit ratio of selected sample. As per the Gross Profit Ratio of the SBI Life Insurance and HDFC Standard Life Insurance during the period of the study from 2014-15 to 2018-19. In SBI Life Insurance Shows Mix Trend With an average 89.70 which is highest in the selected sample the ratio moved between 92.28 in 2016-17 to 91.27 in 2018-19 during the period of study. The Gross Profit ratio of HDFC standard life insurance shows Mix trend with an average 88.87 which is second in the selected selected sample the ratio moved between 90.22 in $2016-17$ to 79.89 in $2018-19$ during the period of the study.

\subsection{Based on Net Profit Ratio}

The Net Profit ratio of selected sample. As per the Net Profit Ratio of the SBI Life Insurance and HDFC Standard Life Insurance during the period of the study from 2014-15 to 2018-19. In SBI Life Insurance Shows Mix Trend With an average 87.66 which is highest in the selected sample the ratio moved between 90.39 in 2016-17 to 88.21 in 2018-19 during the period of study. The Net Profit ratio of HDFC standard life insurance shows Mix trend with an average 87.18 which is second in the selected sample the ratio moved between 88.05 in $2016-17$ to 79.04 in 2018-19 during the period of the study.

\subsection{Based on Return on Total Assets}

The Retune on Total Assets ratio of selected sample. As per the Return on Total Assets of the SBI Life Insurance and HDFC Standard Life Insurance during the period of the study from 2014-15 to 2018-19. In SBI Life Insurance Shows Mix Trend With an average 0.98 which is lowest in the selected sample the ratio moved between 0.93 in 2016-17 to 0.90 in 2018-19 during the period of study. The Return on Total Assets of HDFC standard life insurance shows Mix trend with an average 1.03 which is second in the selected sample the ratio moved between 0.94 in 2016-17 to 0.98 in 2018-19 during the period of the study.

\subsection{Based on Current Ratio}

The Current ratio of selected sample. As per the Current Ratio of the SBI Life Insurance and HDFC Standard Life Insurance during the period of the study from 2014-15 to 2018-19. In SBI Life Insurance Shows Mix Trend With an average 11.47 which is lowest in the selected sample the ratio moved between 17.76 in 2016-17 to 1.78 in 2018-19 during the period of study. The Current Ratio of HDFC standard life insurance shows continuously decreasing trend with an average 13.19 which is second in the selected sample the ratio moved between 15.93 in $2016-17$ to 3.09 in $2018-19$ during the period of the study.

\subsection{Based on Quick Ratio}

The Quick ratio of selected sample. As per the Quick Ratio of the SBI Life Insurance and HDFC Standard Life Insurance during the period of the study from 2014-15 to 2018-19. In SBI Life Insurance Shows Mix Trend With an average 11.47 which is lowest in the selected sample the ratio moved between 17.76 in $2016-17$ to 1.78 in 2018-19 during the period of study. The Quick Ratio of HDFC standard life insurance shows continuously decreasing trend with an average 13.19 which is second in the selected sample the ratio moved between 15.93 in 2016-17 to 3.09 in 2018-19 during the period of the study.

\section{Conclusion}

The process of research can be painstakingly time consuming. It can involve the overcoming of many obstacles and may unfortunately need to be revised several times as you progress through the steps. By completing your study in 
the correct order and making sure you don't forget important tasks, your progression from theory to publication will occur much more smoothly.

\section{References}

[1] Kishore. R. B. (2001) "A Holistic View of Insurance Reforms and a Blue Print for Strengthening LIC", The Indian Journal, Jan-June, P 35.

[2] Kapse S. and Kodwanid G (2003) "Insurance as an Investment Option" International Journal of Computer Science \& Management Studies, July 2014.

[3] Krishnamurthy S, Mony S. V., Jhaveri N., Bakhshi S, Bhat S and Dixit M. R. (2005) "Insurance Industry in India: Structure, Performance and Future Challenges" International Journal of Computer Science \& Management Studies, July 2014.

[4] Rastogi S., and Sarkar R., (2006) "Competitiveness among the Indian life insurers" International Journal of Computer Science \& Management Studies, July 2014.

[5] Raman. N. and Gayathri. C (2006) "A study Customers Awareness towards New Insurance Companies" International Journal of Computer Science \& Management Studies, July 2014.

[6] Murthy R. Babu and Ansari D., (2009) "The Performance of Life Insurance Corporation of India" International Journal of Computer Science \& Management Studies, July 2014.

[7] Bodla, B. S., \& Verma, S. R. (2007). Life Insurance Policies in Rural Area Understanding Buyer Behavior. ICFAI Journal of Services Marketing, 5 (4).
[8] Barathi, C., Balaji, C. D., \& Meitei, C. I. (2011). Innovative Strategies to Catalyse Growth of Indian Life Insurance SectorAn Analytical Review. Indian Journal of Commerce and Management Studies, 2 (4), 136-145.

[9] Nena, S. (2013). Performance evaluation of Life Insurance Corporation (LIC) of india. International Journal, 1 (7), 113118.

[10] Keerthi, P., \& Vijayalakshmi, R. (2009). A study on the expectations and perceptions of the services in private life insurance companies. SMART Journal of Business Management Studies, 5 (2), 60-64.

[11] Abdulkareem, A. M. (2020). Profitability Performance of HDFC Bank and ICICI Bank: An Analytical and Comparative Study. Global Journal of Management And Business Research.

[12] IremHussanieand Bashir Ahmad Joo (2019),"Determinants of Profitability of Life Insurers in India- Panel Evidence", International Journal of Management Studies, Vol. No. 6 (7), pp. 58-65

[13] Parihar, S. S. (2020). LAPSATION AND SUM ASSURED OF LIFE INSURANCE SECTOR IN INDIA. Prestige International Journal of Management and Research, 12 (1/2), 211-216.

[14] Deyganto, K. O. \& Alemu, A. A. (2019). Factors affecting financial performance of insurance companies operating in Hawassa city administration, Ethiopia. Universal Journal of Accounting and Finance, Vol. 7 (1), Pp. 1-10.

[15] Kumar, M. S., \& Priyan, J. V. (2012). A comparative study of public and private life insurance companies in India. The Indian Journal of Commerce, 65 (1), 81-87. 